\title{
Transcriptome Analysis of White-Rot Fungi in Response to Lignocellulose or Lignocellulose-Derived Material Using RNA Sequencing Technology
}

\author{
Yixing Zhang*, Koichi Yamaura \\ College of International Management, Ritsumeinkan Asia Pacific University, Oita, Japan \\ Email: *yiixingzh@gmail.com
}

How to cite this paper: Zhang, Y.X. and Yamaura, K. (2020) Transcriptome Analysis of White-Rot Fungi in Response to Lignocellulose or Lignocellulose-Derived Material Using RNA Sequencing Technology. Advances in Bioscience and Biotechnology, 11, 355-368.

https://doi.org/10.4236/abb.2020.118025

Received: July 2, 2020

Accepted: August 3, 2020

Published: August 6, 2020

Copyright $\odot 2020$ by author(s) and Scientific Research Publishing Inc. This work is licensed under the Creative Commons Attribution International License (CC BY 4.0).

http://creativecommons.org/licenses/by/4.0/

Open Access

\begin{abstract}
White-rot fungi are the only organisms that can completely degrade all components of lignocellulosic biomass, including the recalcitrant lignin polymer. Lignin degradation is important for the industrial application of lignocellulosic biomass as a raw material for producing value-added chemicals and materials. Therefore, elucidating the lignin degradation mechanism in white-rot fungi will help researchers develop efficient and eco-friendly methods enabling the production of value-added chemicals from lignocellulosic biomass. A transcriptome analysis is an effective way to compare gene expression patterns between different samples under diverse conditions and can provide insights into biological processes. The democratization of next-generation sequencing technology, especially RNA-sequencing, has made transcriptome sequencing and analysis a common research approach for many laboratories. In this review, we focus on the transcriptome profiles of two well-characterized white-rot fungi (Phanerochaete chrysosporium and Dichomitus squalens) in response to various lignocellulosic materials. The application of RNA-seq technology combining with other techniques remains the best approach for investigating fungal secretomes and elucidating the mechanisms of fungal responses to lignocellulose.
\end{abstract}

\section{Keywords}

Transcriptome, RNA-Seq, White-Rot Fungi, Lignocellulosic Biomass

\section{Introduction}

Lignocellulosic biomass, which is the most abundant polymer on Earth, consists 
of cellulose, hemicellulose, and lignin. There is increasing research focused on the utility of lignocellulosic biomass as a sustainable alternative to fossil fuel-based energy sources, biomaterials, and chemicals [1]. The two major industries producing the main sources of lignocellulosic biomass are forestry (e.g., sawdust, logging debris, and bark) and agriculture (e.g., rice, wheat straw, corn stover, and sugar cane bagasse) [1]. Cellulose, which is the major component of lignocellulosic biomass, is highly crystalline, because its glucose subunits are linked by $\beta-1,4$ glycosidic bonds. Hemicellulose is a heterogeneous polymer comprising xylose, arabinose, mannose, and galactose. Additionally, it is hydrolyzed more easily than cellulose because of its amorphous structure [2]. Lignin is also a heterogeneous polymer and is formed from the free radical coupling of methoxy-substituted coniferyl alcohol units [3]. Moreover, lignin represents up to $32 \%$ of plant dry matter [4], and it is the most recalcitrant cell wall component, providing rigidity as well as resistance against microbial infections, while also facilitating water transport [1]. Lignin is the most renewable source of aromatic compounds on Earth [5]. There are many applications for aromatics derived from lignin. For example, they may serve as precursors for the synthesis of biopolymers [6]. Despite its substantial potential as an industrial raw material, lignin remains the least utilized lignocellulosic biomass polymer and is currently being burned to generate heat and electricity [7]. The degradation of lignin is challenging because of its insolubility and complex, random structure with various non-hydrolyzable intramolecular $\mathrm{C}-\mathrm{C}, \mathrm{C}-\mathrm{O}$, and $\beta$-aryl ether bonds [8]. Lignin is currently fragmented via physical or chemical methods, which generate several aromatic compounds such as coumaric acid, hydroxybenzoic acid, ferulic acid, and vanillic acid [9]. The development of an environmentally friendly method for modifying lignin is a high priority for researchers because of the utility of lignin in a thriving bio-based economy.

Although diverse microorganisms can decompose lignocellulose, basidiomycetous white-rot fungi are the only organisms that can degrade all lignocellulosic biomass components, because they produce a variety of extracellular hydrolytic and oxidative enzymes, most of which have been categorized in the Carbohydrate-Active Enzyme (CAZy) database [8] [10]. The resulting monomer sugars serve as carbon and energy sources, and are taken up by the fungal cells through specific pathways [11]. To degrade lignin, white-rot fungi secrete an array of oxidoreductases from the CAZy auxiliary activity (AA) family of enzymes. The key enzymes in this family are fungal class II peroxidases, including lignin peroxidases (LiPs), manganese peroxidases ( $\mathrm{MnPs}$ ), and versatile peroxidases (VPs) [12]. Additionally, laccases, which are phenol-oxidizing multicopper oxidases, help peroxidases degrade lignin in the presence of aromatic compounds [12]. Furthermore, excessive amounts of $\mathrm{H}_{2} \mathrm{O}_{2}$-generating enzymes, such as glucose methanol choline (GMC), alcohol oxidases (AOXs), aryl alcohol oxidases (AAOs), glucose 1-oxidases (GLXs), and copper radical oxidases (CROs), contribute to the lignin-degrading system of white-rot fungi [13]. In addition to lignin-degrading enzymes, white-rot fungi secrete cellulases and hemicellulases 
from glycoside hydrolase (GH) families to completely depolymerize cellulose and hemicellulose [13]. Two other types of enzymes, lytic polysaccharide monooxygenases (LPMOs) and cellobiose dehydrogenases (CDHs), also participate in the degradation process (Figure 1) [14] [15]. Phanerochaete chrysosporium mainly colonizes in hardwoods [16], whereas, Dichomitus squalens are predominantly found on softwoods, but can also grow on hardwoods by tailoring their molecular responses [17]. The genome of P.chrysosporium lacks genes encoding laccase, and mainly produces LiPs and MnPs [16], but D. squalens produces predominantly MnPs and laccases in the lignin degradation process [18]. Both $P$. chrysosporium and $D$. squalens selectively degrade lignin and hemicellulose fraction and leave the cellulose fractions barely untouched [19] [20]. Many studies have been done on the application of $P$. chrysosporium in the biological pretreatment of lignocellulosic biomass (e.g., rice straw, cotton stalks, and wheat straws) and results showed greatly loss of lignin and reduction of the crystalline index of cellulose [21] [22] [23]. However, the application of D. squalens in the biological treatment of lignocellulosic biomass is not common compared to $P$. crysosporium. This review mainly focuses on the published studies regarding the above-mentioned white-rot fungi and their transcriptome responses to lignocellulosic materials. Studies reviewed in this review were selected according to the process described in Figure 2.

\section{Transcriptome Analytical Approaches}

Transcriptomes refer to the complete set of genome sequences transcribed at a specific time-point by a given organism, organ, tissue, or cell [24]. In contrast to static genomic studies, transcriptome analyses are dynamic because they reflect the changes in gene expression due to developmental or environmental conditions [25]. Methods for analyzing transcriptomes, including those involving microarrays and RNA sequencing (RNA-seq), evolved from the massively parallel signature sequencing (MPSS) and serial analysis of gene expression (SAGE) [26].

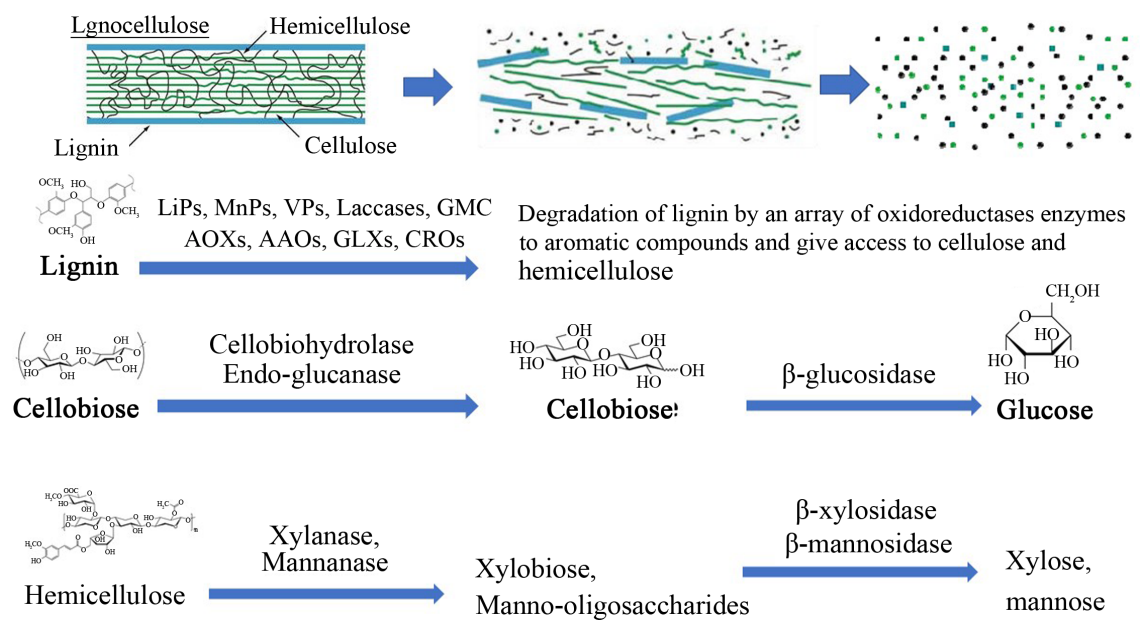

Figure 1. Lignocellulose degradation mechanisms by white-rot fungi, graph was modified based on work by Nobre and Aanen [44]. 


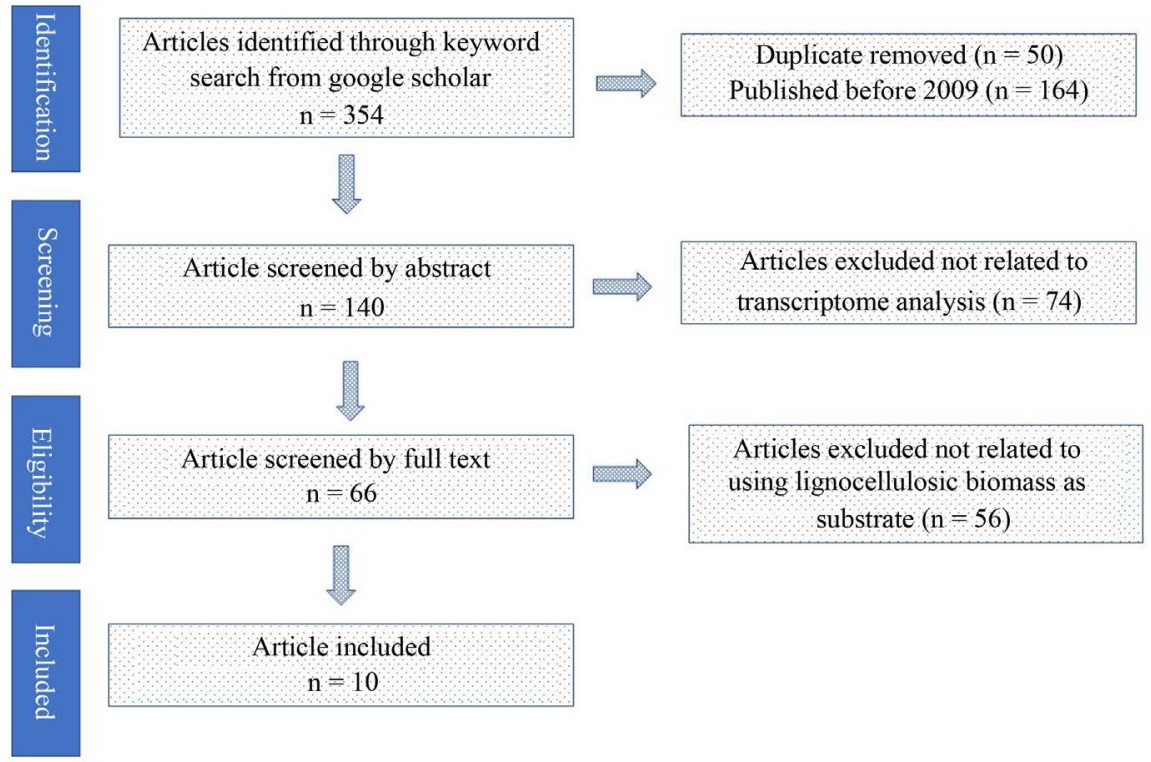

Figure 2. Flow diagram of literature selection process.

Specifically, RNA-seq is a rapid and cost-effective revolutionary technique that exploits the capabilities of next-generation sequencing platforms to generate large numbers of high-quality short reads, thereby enabling comprehensive transcriptomics data mining [26] [27]. Transcriptome research is currently dominated by RNA-seq because it does not require an available reference genome. Furthermore, it can refine the annotation of potential reference genomes as well as identify unpredicted transcribed regions and detect gene splicing variants [28]. The RNA-seq method is based on the sequencing of a considerable abundance of cDNA synthesized from mRNA obtained from the sample under study. The protocol for sequencing the normalized cDNA library varies depending on the specific platform (e.g., Illumina system). Regardless of the system, the raw sequencing data (i.e., millions of reads) undergo a quality control step and the reads are trimmed to obtain clean data. The processed reads are subsequently mapped to a reference genome or a transcriptome, which can be created de novo from the reads if a reference genome is unavailable. The expression of genes can be quantified according to the frequency of reads mapped to the same gene. Reads per thousand nucleotides per million mapped reads (RPKM) or fragments per thousand nucleotides per million mapped reads (FPKM) are frequently used to quantify gene expression levels [28]. Once the expression level information is available, the differentially expressed genes may be analyzed with specific statistical tests. Other downstream analyses may also be performed, including gene annotations, gene set enrichment analyses, or pathway analyses (Figure 3). The RNA-seq approach is especially useful because most white-rot fungal genomes are not completely sequenced and annotated. Moreover, this technique can detect novel genes as well as generate information regarding previously uncharacterized genes. For example, Oghenekaro et al. [29] sequenced and de novo assembled the transcriptome of the white-rot fungus 


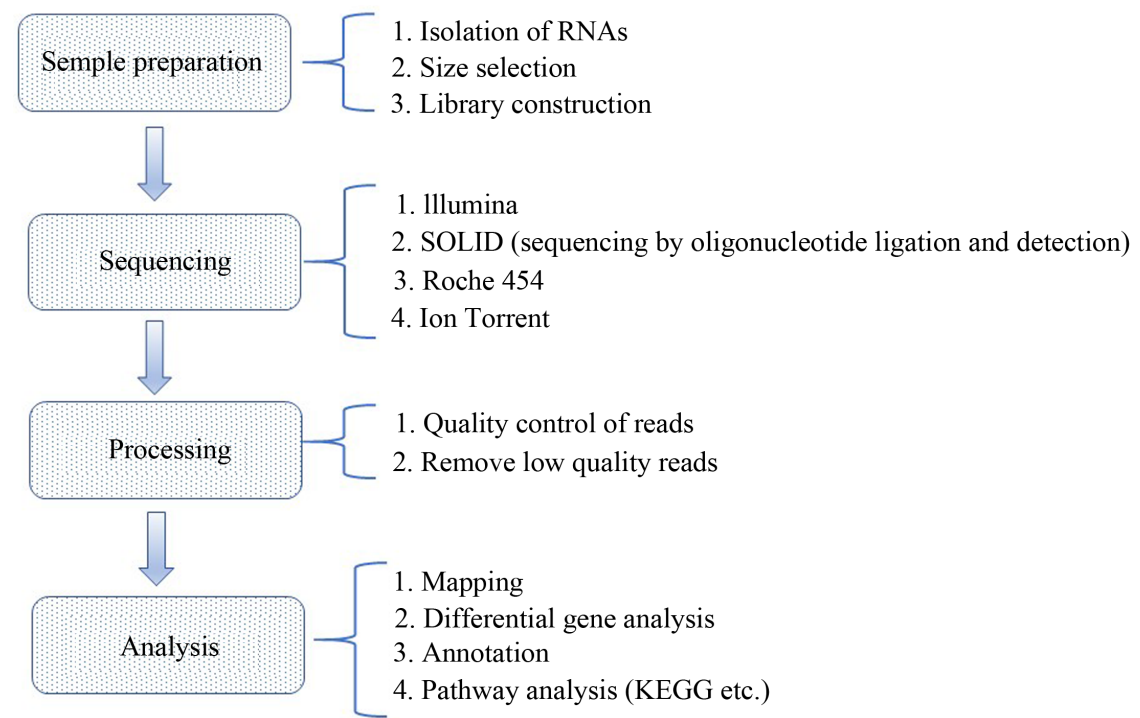

Figure 3. RNA-seq analysis workflow.

Rigidoporus microporus, ultimately producing 25,880 annotated unigenes. Their data revealed that the fungus expresses more than 300 genes encoding lignocellulolytic enzymes, with rubberwood upregulating the expression of 175 genes.

\section{White-Rot Fungi}

\subsection{Phanerochaete Chrysosporium}

The white-rot fungus $P$. chrysosporium is one of the most extensively studied fungi because of its ability to degrade lignocellulosic biomass [30]. It secretes a wide range of oxidative and hydrolytic enzymes to degrade lignin and a variety of organic compounds, including 2,4-dichlorophenol, 2,4-dinitrotoluene, and endosulfan [31]. Martinez et al. [32] fully sequenced and annotated the $P$. chrysosporium genome, which has considerably advanced our understanding of the wood decay mechanism of this fungus. During the last few decades, genome-level transcriptome studies have revealed several important facts about the differential expression patterns of genes involved in lignin depolymerization. Most transcriptome analyses conducted before 2015 involved microarrays. Table 1 summarizes the sample conditions and analytical approaches used in the five P. chrysosporium transcriptome studies described below. Wymelenberg et al. [33] performed secretome and transcriptome analyses using microarrays and liquid chromatography-tandem mass spectrometry (LC-MS/MS) to determine the number, structure, and regulation of genes involved in lignocellulosic cell wall degradation. They identified numerous carbohydrate-active genes, including GH 61 family members, polysaccharide lyases, and carbohydrate esterases. Also, they found that other upregulated genes were involved in the hemicellulose degradation including various xylanases, mannanase, $\alpha$-and $\beta$-galactosidases, polygalacturonase, arabinofuranosidase, xyloglucanases and feruloyl esterase. More than 190 upregulated genes were predicted to encode proteins of 
Table 1. Details of the sample conditions and RNA-seq data analysis approach in P. chrysosporium transcriptome analysis.

\begin{tabular}{|c|c|c|c|c|}
\hline Platform & Substrate & Sample condition & RNA-seq data analysis & Reference \\
\hline $\begin{array}{l}\text { Roche } \\
\text { NimbleGe } \\
\quad \mathrm{n} \\
\text { arrays }\end{array}$ & $\begin{array}{l}\text { microcrystalline } \\
\text { cellulose }\end{array}$ & $\begin{array}{l}\text { Three biological replicates; } \\
\text { total RNA was extracted from } \\
\text { frozen fungi pellets after } \\
5 \text { days incubation at } 37^{\circ} \mathrm{C}\end{array}$ & $\begin{array}{l}\text { NimbleScan v2.4 and ArrayStar v2.1 software was used to } \\
\text { quantify and visualize data. Quantile normalization and robust } \\
\text { multi-array averaging were applied to the entire data set. } \\
\text { Expression levels are based on } \log 2 \text { values. }\end{array}$ & [33] \\
\hline $\begin{array}{l}\text { Roche } \\
\text { NimbleGe } \\
\quad \mathrm{n} \\
\text { arrays }\end{array}$ & $\begin{array}{l}\text { ball-milled } \\
\text { aspen }\end{array}$ & $\begin{array}{l}\text { Three biological replicates; } \\
\text { total RNA was extracted from } \\
\text { frozen fungi pellets after } \\
5 \text { days incubation at } 37^{\circ} \mathrm{C}\end{array}$ & $\begin{array}{l}\text { DNASTAR ArrayStar v2.1 software was used to quantify and } \\
\text { visualize data. Quantile normalization and robust multiarray } \\
\text { averaging were applied to the entire data set. Expression levels } \\
\text { are based on } \log 2 \text { values. T-test with a false discovery rate } \\
\text { threshold at } \mathrm{P}<0.001 \text { was used to determine significant } \\
\text { differences in expression. }\end{array}$ & [34] \\
\hline $\begin{array}{l}\text { Illumina } \\
\text { HiSeq } \\
2000\end{array}$ & $\begin{array}{l}\text { Spruce } \\
\text { wood }\end{array}$ & $\begin{array}{l}\text { Three biological replicates; } \\
\text { total RNA was extracted from } \\
\text { samples at } 40 \mathrm{~h} \text { and } \\
96 \mathrm{~h} \text { incubation at } 38^{\circ} \mathrm{C}\end{array}$ & $\begin{array}{l}\text { DNAStar Inc. modules SeqNGen and Qseq were used for } \\
\text { mapping reads and statistical analysis. The current Joint Genome } \\
\text { Institute (JGI) annotation (v2.2), served as the queried database } \\
\text { RNA-seq-based transcript results are presented as RPKM values }\end{array}$ & [35] \\
\hline $\begin{array}{l}\text { Illumina } \\
\text { HiSeq } \\
4000\end{array}$ & $\begin{array}{l}\text { Maple wood } \\
\text { and } \\
\text { miscanthus }\end{array}$ & $\begin{array}{l}\text { Three biological replicates; } \\
\text { RNA was extracted from } \\
\text { mycelium after } 5 \text { weeks } \\
\text { cultivation at room } \\
\text { temperature. }\end{array}$ & $\begin{array}{l}\text { ArrayStar program of DNASTAR software was used to process } \\
\text { raw data sequences, and annotation was done by using the } \\
P . \text { chrysosporium RP- } 78 \mathrm{v} 2.2 \text { from the Joint Genome Institute } \\
\text { (JGI). RNA-seq transcript-based results were reported } \\
\text { as RPKM values }\end{array}$ & [36] \\
\hline $\begin{array}{l}\text { Illumina } \\
\text { HiSeq } \\
4000\end{array}$ & $\begin{array}{l}\text { Helianthus } \\
\text { argophyllus } \\
\text { (silverleaf } \\
\text { sunflower) } \\
\text { stem }\end{array}$ & $\begin{array}{l}\text { Three biological replicates; } \\
\text { RNA was extracted from } \\
\text { samples after } 6 \text { weeks } \\
\text { incubation at room } \\
\text { temperature }\end{array}$ & $\begin{array}{l}\text { ArrayStar program of DNASTAR software was used to process } \\
\text { the raw data sequences, the annotation was done using } \\
\text { P. chrysosporium RP-78 v2.2 and Gene Ontology (GO) file } \\
\text { (Phchr } 2 \text { _GeneCatalog_proteins_20131210 } \\
\text { _GO.tab.gz) from the Joint Genome Institute (JGI). } \\
\text { NCBI nucleotide BLAST was further used to annotate transcripts } \\
\text { of interests. The data were represented as RPKM values. }\end{array}$ & [37] \\
\hline
\end{tabular}

unknown function, among which, approximately one-third contain predicted secretion signals. Additionally, 54 encoded proteins were detected in extracellular filtrates. Researchers subsequently compared the gene expression patterns of the white-rot fungus $P$. chrysosporium and the brown-rot fungus Postia placenta colonized on aspen [34]. This earlier investigation proved that the oxidoreductase-encoding genes have distinct expression patterns in brown-rot and white-rot fungi. $P$. chrysosporium was observed to secrete an array of extracellular glycosyl hydrolases to simultaneously degrade cellulose and hemicellulose. In contrast, $P$. placenta secreted various hemicellulases, but few potential cellulases, under the same conditions. $P$. chrysosporium identified 35 significantly differential expressed genes in ball-milled aspen (BMA), among which, 22 genes identified as glycosyl hydrolase family members, including highly expressed upregulated genes encoding exocellobiohydrolase GH7 and exocellobiohydrolase GH6. However, in P. placenta, only 5 glycoside hydrolase-encoding genes were upregulated in BMA, while a broadly defined hemicellulose (e.g., endo- $\beta$-1,4mannosidases, endoxylanases, mannosidases, and $\beta$-xylosidase) genes were highly expressed in BMA. Furthermore, the genes related to iron-acquisition systems were differentially expressed between these two species. In P. placenta, the expression levels of genes encoding ferroxidase and iron permease were sub- 
stantially upregulated, which is in contrast to the downregulated expression of these genes in $P$. chrysosporium. Korripally et al. [35] characterized the changes in gene expression during the transition to ligninolytic metabolism using fluorometric oxidant-sensing beans in conjunction with a whole-transcriptome shot-gun sequencing analysis. This study revealed 356 upregulated genes and 252 downregulated genes. The upregulated genes encoding LiPs, MnPs, and auxiliary enzymes, and suggested that the extracellular oxygen species involved in ligninolytic reactions are generated from $\mathrm{MnP}$-catalyzed lipid peroxidation, $\mathrm{CDH}$-catalyzed $\mathrm{Fe}^{3+}$ reduction, and oxidase-catalyzed $\mathrm{H}_{2} \mathrm{O}_{2}$ production. Moreover, this study identified 72 unknown protein-encoding genes with upregulated expression at $96 \mathrm{~h}$, including 27 putative transporter genes and 18 cytochrome P450 genes as candidates for future studies on lignin fragment uptake and processing. Alaradi [36] examined the transcriptome of $P$. chrysosporium after 5 weeks of growth on maple (hardwood) and miscanthus (energy grass). In this study, $P$. chrysosporium responded uniquely to maple and miscanthus, with 55 and 66 differentially expressed genes identified when samples growing on maple and miscanthus were compared with those growing under control conditions, respectively. Many of the identified genes are involved in the breakdown of lignocellulose, including $\mathrm{LiP}, \mathrm{MnP}$, and GH genes. However, more than half of these genes are not well annotated regarding their effects on maple and miscanthus. Moreover, malate synthase, lactate dehydrogenase, and phosphoenolpyruvate carboxykinase genes were more highly expressed in fungi grown on miscanthus than in fungi grown on maple. Alsubaie [37] investigated the P. chrysosporium transcriptome by culturing the fungus on sunflower stems after 6 weeks of growth. In this study, 102 genes were identified differentially expressed when compared to control condition, the majority of these genes were tied to lignocellulose degradation including peroxidases, oxidases, and glycoside hydrolases, however, up to $75 \%$ of the differentially expressed genes were classified as hypothetical or unknown.

\subsection{Dichomitus Squalens}

Dichomitus squalens is a white-rot basidiomycete that degrades cellulose and lignin by secreting hydrolytic and oxidative enzymes. The $D$. squalens genome includes genes predicted to encode four cellobiohydrolases ( $\mathrm{CBHs}$ ), three putative endoglucanases, six putative $\beta$-glucosidases, one putative $\mathrm{CDH}$, and 15 LPMOs [38], as well as other genes encoding enzymes involved in lignocellulose degradation (e.g., nine MnPs and 11 laccases) [39]. The ability to secrete diverse extracellular lignocellulose-modifying enzymes has made $D$. squalens an excellent model fungus for studying lignocellulose degradation. Research has been conducted on the molecular response of D. squalens to lignocellulose or lignocellulose-derived compounds as well as the underlying regulatory system. Table 2 summarizes the sample conditions and analytical approaches used in the five D. squalens transcriptome studies described below. Rytioja et al. [39] analyzed 10 genes encoding cellulose-acting enzymes in $D$. squalens on solid-state spruce 
Table 2. details of the sample conditions and RNA-seq data analysis approach in D. squalens transcriptome analysis.

\begin{tabular}{|c|c|c|c|c|}
\hline Platform & Substrate & Sample condition & RNA-seq data analysis & Reference \\
\hline $\begin{array}{c}\text { Maxima SYBR } \\
\text { Green qPCR Master } \\
\text { Mix and ABI apparatus } \\
\text { (Applied Biosystem) }\end{array}$ & $\begin{array}{l}\text { Spruce wood, } \\
\text { Microcrystalline } \\
\text { cellulose (Avicel) }\end{array}$ & $\begin{array}{l}\text { Three biological replicates; } \\
\text { total RNA was extracted from } \\
\text { fungal } \\
\text { mycelia growing on spruce } \\
\text { wood at } \\
28^{\circ} \mathrm{C} \text { at } 7,14,21 \text {, and } 28 \text { days; } \\
\text { total RNA was extracted from } \\
\text { fungal mycelia growing with } \\
\text { Avicel cultures at } 14 \text { and } 28 \\
\text { days. }\end{array}$ & $\begin{array}{l}\text { Differences in the gene expression levels } \\
\text { were estimated according to the Shapiro-Wilk } \\
\text { normality test at } \mathrm{P} \geq 0.05 \text {. Normal distribution } \\
\text { was done for genes cel } b \text { and lpmol based on } \\
\text { two biological replicates of fungi growing with } \\
\text { Avicel at } 14 \text { days. Repeated measures ANOVA } \\
\text { was used to estimate the variation in the } \\
\text { expression of one gene in different time points } \\
\text { for spruce wood cultures and paired samples } \\
\text { t-test for Avicel cultures at P-value }<0.05 \text {. }\end{array}$ & [39] \\
\hline $\begin{array}{c}\text { DNBseq } \\
\text { Technology }\end{array}$ & $\begin{array}{l}\text { Aspen, } \\
\text { spruce wood, } \\
\text { wheat bran, } \\
\text { cottonseed hulls }\end{array}$ & $\begin{array}{l}\text { Total RNA was extracted from } \\
\text { mycelia from two biological } \\
\text { replicate cultures after } 9 \text { days } \\
\text { and } 16 \text { days' cultivation at } 28^{\circ} \mathrm{C}\end{array}$ & $\begin{array}{l}\text { Reads were mapped to the genome sequence } \\
\text { of } D \text {. squalensLYAD- } 421 \text { SS1 (v1.0 annotation, } \\
\text { the Joint Genome Institute (JGI)) using } \\
\text { SOAPALIGNER/SOAP2. RPKM was used to } \\
\text { quantify RNA-seq results, Differential expression } \\
\text { was identified by CyberT Bayesian ANOVA } \\
\text { algorithm at a cut-off value of the fold change } \\
\text { of }>1.5 \text { and P-value (corrected by multiple tests) } \\
\text { of }<0.05 \text {. }\end{array}$ & [40] \\
\hline & & & $\begin{array}{l}\text { Reads were aligned to the reference genome } \\
\text { (https://genome.jgi.doe.gov/Dicsqu464_1/Dicsqu4 }\end{array}$ & \\
\hline $\begin{array}{l}\text { Illumina } \\
\text { HiSeq } 2000 \\
\text { platform }\end{array}$ & $\begin{array}{l}\text { Norway spruce } \\
\text { (Piceaabies), } \\
\text { silver birch } \\
\text { (Betula pendula) }\end{array}$ & $\begin{array}{l}\text { Three biological replicates; } \\
\text { total RNA was extracted } \\
\text { from mycelium after } 2 \text { weeks } \\
\text { and } 4 \text { weeks cultivation at } 28^{\circ} \mathrm{C}\end{array}$ & $\begin{array}{l}\text { 64_1.home.html) using HISAT version } 0.1 .4 \text {-beta. } \\
\text { Differentially expressed genes were identified } \\
\text { using DESeq2 (version } 1.10 .0 \text { ) with a cutoff } \\
\text { value of adjusted p-value }<0.05 \text {. Raw gene } \\
\text { counts were used for DGE analysis as } \\
\text { DESeq2 uses its internal normalization. }\end{array}$ & {$[41]$} \\
\hline $\begin{array}{l}\text { Illumina } \\
\text { HiSeq } 2000 \\
\text { platform }\end{array}$ & $\begin{array}{l}\text { D-glucuronic acid, } \\
\text { D-galacturonic acid, } \\
\text { L-rhamnose, } \\
\text { D-galactose, } \\
\text { D-xylose, } \\
\text { D-mannose, } \\
\text { L-arabinose, } \\
\text { disaccharide } \\
\text { cellobiose }\end{array}$ & $\begin{array}{l}\text { The replication of samples was } \\
\text { not mentioned in this study. } \\
\text { Total RNA was extracted from } \\
\text { the mycelium from the edge } \\
\text { of the colony after } 5 \text { days } \\
\text { of growth at } 28^{\circ} \mathrm{C}\end{array}$ & $\begin{array}{l}\text { Reads were mapped to the genome of } \\
\text { D. squalens CBS } 464.89 \text { using Bowtie } 2 \text { and the } \\
\text { BWA software. The gene expression level was } \\
\text { measured in FPKM using the RSEM tool. } \\
\text { Differential expression was identified by the } \\
\text { DESeq } 2 \text { with a cutoff value of } \geq 2.5 \text {-fold change, } \\
\text { FPKM value of } \geq 10 \text {, and the adjusted P-value } \\
\text { of } \leq 0.01 \text {. CAZyme annotations were done } \\
\text { using JGI MycoCosm website } \\
\text { (https://genome.jgi.doe.gov/mycocosm/proteins-b }\end{array}$ & {$[42]$} \\
\hline $\begin{array}{l}\text { Illumina } \\
\text { HiSeq } 2500 \\
\text { platform }\end{array}$ & $\begin{array}{l}\text { coniferyl alcohol, } \\
\text { ferulic acid, vanillin, } \\
\text { vanillyl alcohol, } \\
\text { vanillic acid, } \\
\text { veratryl alcohol, } \\
\text { protocatechuic acid, } \\
\text { p-coumaric acid, } \\
\text { p-hydroxybenzoic } \\
\text { acid, and } \\
\text { cinnamic acid. }\end{array}$ & $\begin{array}{l}\text { Three biological replicates; } \\
\text { RNA was extracted from } \\
\text { cultivation for } 4 \text { days at } 28^{\circ} \mathrm{C} \text {. }\end{array}$ & $\begin{array}{l}\text { rowser/browse;qLeIA4?p=Dicsqu464_1). } \\
\text { Gene expression levels were measured as FPKM. } \\
\text { DESeq2 version } 1.10 .0 \text { was used to compare the } \\
\text { transcript level of samples. Differentially expressed } \\
\text { genes were identified with fold change > 2, } \\
\text { adjusted p < 0.01, and FPKM > } 10 \text { in at least one } \\
\text { condition between each pair of conditions. } \\
\text { Functional annotation of differentially expressed } \\
\text { genes was based on combined information from } \\
\text { EuKaryotic Orthologous Groups (KOG), Kyoto } \\
\text { Encyclopedia of Genes and Genomes (KEGG) } \\
\text { pathway mapping, InterPro protein sequence } \\
\text { analysis and classification, and } \\
\text { Carbohydrate-active enzymes (CAZy) } \\
\text { classifications for D. squalens CBS464.89 } \\
\text { (Dicsqu464_1) retrieved from JGI MycoCosm } \\
\text { database (https://genome.jgi.doe. } \\
\text { gov/cgi-bin/kogBrowser?db=Dicsqu464_1) }\end{array}$ & {$[43]$} \\
\hline
\end{tabular}


wood and in microcrystalline-supplemented cultures. These genes included three ( $c e h a, c e l h b$, and $c e h c$ ) encoding CBHI, one (cel6) encoding CBHII, one encoding $\mathrm{CDH}$, and five putative LPMO-encoding genes (Ipmo1, Ipmo2, Ipmo3, Ipmo4, and Ipmo5). Additionally, ceh a was expressed constitutively and was the most abundant transcript, whereas the other cel genes were expressed at low levels in fungi growing on spruce wood and in Avicel. Moreover, lpmo genes encoding a cellulose-binding module (CBM) were observed to be more highly expressed than those lacking a CBM sequence when $D$. squalens was grown on spruce wood, whereas these genes were similarly transcribed in the liquid Avicel cultures. Although the $\mathrm{CDH}$-encoding gene was co-expressed with the Ipmo genes, its expression level was low in fungi grown on spruce wood and in Avicel cultures. Rytioja et al. [40] analyzed the transcriptome and exoproteome of $D$. squalens grown on two woody (aspen and spruce wood) and two non-woody plant biomasses (wheat bran and cotton seed hulls). Total 297 genes were identified as differentially expressed, of which, 135 genes were related to plant cell wall degradation. The number of expressed cellulolytic genes increased in both spruce and aspen, while decreased or not changed in non-woody plant biomass in the course of cultivation. The genes encoding ligninolytic enzymes, including AA2 lignin-modifying peroxidases and AA1_1 laccases, were mainly expressed on day 9 in the woody samples, whereas most cellulase gene expression levels were higher on day 16 than on day 9, implying the fungus degraded lignin first to make the cellulose accessible. The ligninolytic enzyme genes were expressed at lower levels in the non-woody plant biomass (i.e., wheat bran and cottonseed hulls) with low lignin contents than in the woody biomass. The genes for $\mathrm{H}_{2} \mathrm{O}_{2}$-generating enzymes, including $\mathrm{AA} 3$ _3 alcohol/methanol oxidases and AA5_1 CROs, were expressed at similar levels in all substrates, suggesting these enzymes may contribute to the electron transfer system together with LPMOs degrading lignocellulose. A subsequent investigation of the ability of D. squalens to degrade softwood (spruce) and hardwood (birch) materials suggested the fungal molecular responses were more adapted to the softwood material, with a greater abundance of mannanolytic enzymes at the transcript and protein levels in the spruce culture due to the higher mannose content in spruce. Contrasting trends were observed that the genes encoding xylanolytic enzymes were higher expressed, but the activity of xylanolytic enzymes were low in spruce culture. Moreover, the expression level of laccases genes was higher in the birch cultures compared with the spruce cultures. In contrast to laccases, MnPs encoding genes were more abundantly produced in spruce culture [41]. López et al. [42] conducted a transcriptome analysis to examine six lignocellulose-derived sugars known to induce the expression of lignocellulolytic genes in ascomycetes to clarify their role as inducers in the basidiomycetous white-rot fungus $D$. squalens. When compared to D-glucose, 83 significantly upregulated genes were detected among all six lignocellulose-derived sugars, of which, 26 and 27 genes response exclusively to L-rhamnose and cellobiose, respectively. L-rhamnose and cellobiose were identified as the main inducers of cellulolytic and pectinolytic genes, 
respectively. Moreover, lignin-degradation related enzyme encoding genes were induced only by L-rhamnose and D-xylsoe. Dikaryotic and monokaryotic strains of $D$. squalens cultivated on plant biomass-derived monosaccharides and the disaccharide cellobiose varied regarding gene expression patterns, with the largest difference observed on L-rhamnose. Dikaryotic strains showed higher upregulation for ligninolytic enzymes encoding genes than the monokaryotic strains, instead, the monokaryotic strains showed higher upregulation for pectinolytic genes than the dikaryon. Genes encoding mannanases and expansin-like proteins were only induced in dikaryotic strains of $D$. squalens. Accordingly, the fine-tuning of the gene regulation related to lignocellulose conversion may differ between these strains. Kowalczyk et al. [43] identified the various aromatic compounds generated by $D$. squalens cultivated on spruce wood. The $D$. squalens transcriptome-level differences induced by 10 different lignocellulose-related aromatic monomers were analyzed and 268 upregulated genes were identified. Vanillin upregulated the largest set of genes and most of the genes were associated with metabolism, followed by cinnamic acid upregulated the second large set of genes. The previous transcriptome analysis from mono-and dikaryotic strains demonstrated that L-rhamnose trigger the expression of ligninolytic enzymes and the lignin-rich substrate was the key factor that cause the induction of ligninolytic genes in D.squalens [40] [42]. Not as the same as in the previous studies, the lignin-degrading enzymatic machinery was only partially induced by the monomeric aromatic compound in Kowalczyk' study. The expression levels of lignocellulose degradation-related genes as well as transporter-encoding genes and catabolic pathway genes differed significantly between the fungal samples supplemented with different aromatic compounds. The results also demonstrated that the regulon induced in the presence of aromatic compounds differs regarding the number and function of the genes. Vanillin, cinnamic acid, and p-coumaric acid were the main inducers of the genes annotated with gene ontology (GO) terms related to oxidoreductase activity, whereas the genes annotated with GO terms associated with lignocellulolytic activities were primarily upregulated by coniferyl alcohol, ferulic acid, and vanillyl alcohol.

\section{Conclusion}

In summary, because white-rot fungi can completely degrade all lignocellulosic biomass components, they are potentially useful for producing various bio-based products. Clarifying the molecular mechanisms mediating the lignocellulose degradation by white-rot fungi may facilitate the application of these fungi for metabolic engineering and optimize the bioconversion of renewable biomass resources to chemicals. The application of RNA-seq technology to analyze transcriptomes has increased our understanding of gene expression and may be useful for revealing the expression patterns of previously unannotated and noncoding genomic regions. Combining transcriptome sequencing with other techniques (e.g., secretomics-, NMR-, and mass spectrometry-based analyses) remains the best approach for investigating fungal secretomes and elucidating the 
mechanisms underlying fungal responses to lignocellulose.

\section{Acknowledgements}

This work was supported by the Japan Society for the Promotion of Science (JSPS) funding No. 17F17404.

\section{Conflicts of Interest}

The authors declare no conflicts of interest regarding the publication of this paper.

\section{References}

[1] Tolbert, A., Akinosho, H., Khunsupat, R., Naskar, A.K. and Ragauskas, A.J. (2014) Characterization and Analysis of the Molecular Weight of Lignin for Biorefining Studies. Biofuels, Bioproducts and Biorefining, 8, 836-856. https://doi.org/10.1002/bbb.1500

[2] Gibson, L.J. (2013) The Hierarchical Structure and Mechanics of Plant Materials. Journal of the Royal Society Interface, 9, 2749-2766. https://doi.org/10.1098/rsif.2012.0341

[3] Adler, E. (1977) Lignin Chemistry-Past, Present, and Future. Wood Science and Technology, 11, 169-218. https://doi.org/10.1007/BF00365615

[4] Kirk, T.K. (1983) Degradation and Conversion of Lignocelluloses. Edward Arnold, London

[5] Mäkelä, M.R., Marinovic, M., Nousiainen, P., Liwanag, A.J.M., Benoit, I., Sipila, J., et al. (2015) Aromatic Metabolism of Filamentous Fungi in Relation to the Presence of Aromatic Compounds in Plant Biomass. Advances in Applied Microbiology, 91, 63-137. https://doi.org/10.1016/bs.aambs.2014.12.001

[6] Kohlstedt, M., Starck, S., Barton, N., Stolzenberger, J., Selzer, M., Mehlmann, K., et al. (2018) From Lignin to Nylon: Cascaded Chemical and Biochemical Conversion Using Metabolically Engineered Pseudomonas putida. Metabolic Engineering, 47, 279-293. https://doi.org/10.1016/j.ymben.2018.03.003

[7] Rinaldi, R., Jastrzebski, R., Clough, M.T., Ralph, J., Kennema, M., Bruijnincx, P.C.A., et al. (2016) Paving the Way for Lignin Valorisation: Recent Advances in Bioengineering, Biorefining and Catalysis. Angewandte Chemie International Edition, 55, 8164-8215. https://doi.org/10.1002/anie.201510351

[8] Hatakka, A. and Hammel, K.E. (2011) Fungal Biodegradation of Lignocelluloses. In: Hofrichter, M., Ed., Industrial Applications, Springer, Berlin, 319-340. https://doi.org/10.1007/978-3-642-11458-8_15

[9] Li, C., Zhao, X., Wang, A., Huber, G.W. and Zhang, T. (2015) Catalytic Transformation of Lignin for the Production of Chemicals and Fuels. Chemical Reviews, 115, 11559-11164. https://doi.org/10.1021/acs.chemrev.5b00155

[10] Lombard, V., Golaconda Ramulu, H., Drula, E., Coutinho, P.M. and Henrissat, B. (2013) The Carbohydrate-Active Enzymes Database (CAZy) in 2013. Nucleic Acids Research, 42, D490-D495. https://doi.org/10.1093/nar/gkt1178

[11] Khosravi, C., Benocci, T., Battaglia, E., Benoit, I. and deVries, R.P. (2015) Sugarcatabolism in Aspergillus and Other Fungi Related to the Utilization of Plant Biomass. Advances in Applied Microbiology, 90, 1-28. https://doi.org/10.1016/bs.aambs.2014.09.005 
[12] Zhao, C., Xie, S., Pu, Y., Zhang, R., Huang, F., Ragauskas, A.J. and Yuan, J.S. (2016) Synergistic Enzymatic and Microbial Lignin Conversion. Green Chemistry, 18, 1306-1312. https://doi.org/10.1039/C5GC01955A

[13] Rytioja, J., Hildén, K., Yuzon, J., Hatakka, A., de Vries, R.P. and Mäkelä, M.R. (2014) Plantpolysaccharide-Degrading Enzymes from Basidiomycetes. Microbiology and Molecular Biology Reviews, 78, 614-649. https://doi.org/10.1128/MMBR.00035-14

[14] Langston, J.A., Shaghasi, T., Abbate, E., Xu, F., Vlasenko, E. and Sweeney, M.D. (2011) Oxidoreductive Cellulose Depolymerization by the Enzymes Cellobiose Dehydrogenase and Glycoside Hydrolase 61. Applied and Environmental Microbiology, 77, 7007-7015. https://doi.org/10.1128/AEM.05815-11

[15] Vaaje-Kolstad, G., Westereng, B., Horn, S.J., Liu, Z., Zhai, H., Sörlie, M. and Eijsink, V.G.H. (2010) An Oxidative Enzyme Boosting the Enzymatic Conversion of Recalcitrant Polysaccharides. Science, 330, 219-222. https://doi.org/10.1126/science.1192231

[16] Andlar, M., Rezić T., Marđetko, N., Kracher, D., Ludwig, R. and Šantek, B. (2018) Lignocellulose Degradation: An Overview of Fungi and Fungal Enzymes Involved in Lignocellulose Degradation. Engineering in Life Sciences, 18, 768-778. https://doi.org/10.1002/elsc.201800039

[17] Blanchette, R., Otjen, L. and Carlson, M. (1987) Lignin Distribution in Cell Walls of Birch Wood Decayed by White Rot Basidiomycetes. Phytopathology, 77, 684-690. https://doi.org/10.1094/Phyto-77-684

[18] Hatakka, A. (1994) Lignin-Modifying Enzymes from Selected White-Rot Fungi: Production and Role From in Lignin Degradation. FEMS Microbiology Reviews, 13, 125-135. https://doi.org/10.1111/j.1574-6976.1994.tb00039.x

[19] Suzuki, H., MacDonald, J., Syed, K., Salamov, A., et al. (2012) Comparative Genomics of the White-Rot Fungi Phanerochaete carnosa and P. chrysosporium, to Elucidate the Genetic Basis of the Distinct Wood Types They Colonize. BMC Genomics, 13, 444-460. https://doi.org/10.1186/1471-2164-13-444

[20] Isroi, S., Millati, R., Syamsiah, S., Niklasson, C., Cahyanto, M.L., Knut, T. and Taherzadeh, M. (2011) Biological Pretreatment of Lignocelluloses with White-Rot Fungi and Its Applications: A Review. Bioresources, 6, 5224-5259.

[21] Bak, J.S., Ko, J.K., Choi, I.-G., Park, Y.-C., Seo, J.-H. and Kim, K.H. (2009) Fungal Pretreatment of Lignocellulose by Phanerochaete chrysosporium to Produce Ethanol from Rice Straw. Biotechnology \& Bioengineering, 104, 471-482. https://doi.org/10.1002/bit.22423

[22] Kerem, Z., Friesem, D. and Hadar, Y. (1992) Lignocellulose Degradation during Solid-State Fermentation: Pleurotus ostreatus versus Phanerochaete chrysosporium. Applied and Environmental Microbiology, 58, 1121-1127. https://doi.org/10.1128/AEM.58.4.1121-1127.1992

[23] Zeng, J., Singh, D. and Chen, S. (2011) Biological Pretreatment of Wheat Straw by Phanerochaete chrysosporium Supplemented with Inorganic Salts. Bioresource Technology, 2, 3206-3214. https://doi.org/10.1016/j.biortech.2010.11.008

[24] Meijueiro, M., Santoyo, F., Ramírez, L. and Pisabarro, A. (2014) Transcriptome Characteristics of Filamentous Fungi Deduced Using High-Throughput Analytical Technologies. Briefings in Functional Genomics, 13, 440-450. https://doi.org/10.1093/bfgp/elu033

[25] Bhadauria, V., Popescu, L., Zhao W.S., et al. (2007) Fungal Transcriptomics. Microbiological Research, 162, 285-298. https://doi.org/10.1016/j.micres.2007.06.006 
[26] Wong, M.M., Cannon, C.H. and Wickneswari, R. (2011) Identification of Lignin Genes and Regulatory Sequences Involved in Secondary Cell Wall Formation in Acacia auriculiformis and Acacia mangium via de Novo Transcriptome Sequencing. BMC Genomics, 12, 342. https://doi.org/10.1186/1471-2164-12-342

[27] Li, H., Dong, Y., Yang, J., Liu, X., Wang, Y., Yao, N., et al. (2012) De Novo Transcriptome of Safflower and the Identification of Putative Genes for Oleosin and the Biosynthesis of Flavonoids. PLOS ONE, 7, e30987.

https://doi.org/10.1371/journal.pone.0030987

[28] Korpelainen, E., Tuimala, J., Somervuo, P., Huss, M. and Wong, G. (2014) RNA-seq Data Analysis a Practical Approach. CRC Press, Boca Raton. https://doi.org/10.1201/b17457

[29] Oghenekaro, A.O., Raffaello, T., Kovalchuk, A. and Asiegbu, F.O. (2016) De novo Transcriptomic Assembly and Profiling of Rigidoporus microporous during Saprotrophic Growth on Rubberwood. BMC Genomics, 17, Article No. 234. https://doi.org/10.1186/s12864-016-2574-9

[30] Singh, D. and Chen, S. (2008) The White-Rot Fungus Phanerochaete chrysosporium: Conditions for the Production of Lignin-Degrading Enzymes. Applied Microbiology and Biotechnology, 81, 399-417. https://doi.org/10.1007/s00253-008-1706-9

[31] Reddy, G.V.B. and Gold, M.H. (2000) Degradation of Pentachlorophenol by Phanerochaete chrysosporium: Intermediates and Reactions Involved. Microbiology, 146, 405-413. https://doi.org/10.1099/00221287-146-2-405

[32] Martinez, D., et al. (2004) Genome Sequence of the Lignocellulose Degrading Fungus Phanerochaete chrysosporium Strain RP78. Nature Biotechnology, 22, 695-700. https://doi.org/10.1038/nbt967

[33] Wymelenberg, A.V., Gaskell, J., Mozuch, M., Kersten, P., Sabat, G., Martinez, D. and Cullen, D. (2009) Transcriptome and Secretome Analyses of Phanerochaete chrysosporium Reveal Complex Patterns of Gene Expression. Applied and Environmental Microbiology, 75, 4058-4068. https://doi.org/10.1128/AEM.00314-09

[34] Wymelenberg, A.V., et al. (2010) Comparative Transcriptome and Secretome Analysis of Wood Decay Fungi Postia placenta and Phanerochaete chrysosporium. Applied and Environmental Microbiology, 76, 3599-3610.

https://doi.org/10.1128/AEM.00058-10

[35] Korripally, P., Hunt, C.G., Houtman, C.J., Jones, D.C., Kitin, P.J., Cullen, D. and Hammel, K.E. (2015) Regulation of Gene Expression during the Onset of Ligninolytic Oxidation by Phanerochaete chrysosporium on Spruce Wood. Applied and Environmental Microbiology, 81, 7802-7812.

https://doi.org/10.1128/AEM.02064-15

[36] Alaradi, M.R. (2017) The Transcriptome Response of the White-Rot Fungus Phanerochaete chrysosporium to Maple and Miscanthus. Unpublished Master Thesis, Eastern Illinois University, Charleston.

[37] Alsubaie, N.H. (2019) The Transcriptional Response of Phanerochaete chrysosporium and Trametes versicolor to Growth on Stems of Helianthus argophyllus (Silverleaf Sunflower). Unpublished Master Thesis, Eastern Illinois University, Charleston.

[38] Floudas, D., Binder, M., Riley, R., Barry, K., Blanchette, R.A., Henrissat, B., et al. (2012) The Paleozoic Origin of Enzymatic Lignin Decomposition Reconstructed from 31 Fungal Genomes. Science, 336, 1715-1719. https://doi.org/10.1126/science.1221748

[39] Rytioja, J., Hildén, K., Hatakka, A. and Mäkelä, M.R. (2014) Transcriptional Analy- 
sis of Selected Cellulose-Acting Enzymes Encoding Genes of the White-Rot Fungus Dichomitus squalens on Spruce Wood and Microcrystalline Cellulose. Fungal Genetics and Biology, 72, 91-98. https://doi.org/10.1016/j.fgb.2013.12.008

[40] Rytioja, J., Hilden, K., Faico, M.D., Zhou, M.M., Aguilar-Pontes, M.V., Sietio, O., Tsang, A., de Vries, R.P. and Mäkelä, M.R. (2017) The Molecular Response of the White-Rot Fungus Dichomitus squalens to Wood and Non-Woody Biomass as Examined by Transcriptome and Exoproteome Analysis. Environmental Microbiology, 19, 1237-1250. https://doi.org/10.1111/1462-2920.13652

[41] Daly, P., López, S.C., Peng, M., Lancefield, C.S., Purvine, S.O., Kim, Y.M., Zink, E.M., et al. (2018) Dichomitus squalens Partially Tailors Its Molecular Responses to the Composition of Solid Wood. Environmental Microbiology, 20, 4141-4156. https://doi.org/10.1111/1462-2920.14416

[42] López, S.C., Peng, M., Issak, T.Y., Daly, P., de Vries, R.P. and Mäkelä, M.R. (2018) Induction of Plant Cell Wall Degrading CAZyme Encoding Genes by Lignocellulose-Derived Monosaccharides and Cellobiose in the White-Rot Fungus Dichomitus squalens. Applied and Environmental Microbiology, 84, e00403-18. https://doi.org/10.1128/AEM.00403-18

[43] Kowalczyk, J.E., Peng, M., Pawlowski, M., Lipzen, A., Ng, V., Singan, V., Wang, M., Grigoriev, I.V. and Mäkelä1, M.R. (2019) The White-Rot Basidiomycete Dichomitus squalens Shows Highly Specific Transcriptional Response to Lignocellulose-Related Aromatic Compounds. Frontiers in Bioengineering and Biotechnology, 7, 229. https://doi.org/10.3389/fbioe.2019.00229

[44] Nobre, T. and Aanen, D.K. (2012) Fungiculture or Termite Husbandry? The Ruminant Hypothesis. Insects, 3, 307-323. https://doi.org/10.3390/insects3010307 